\title{
ELECTRICAL CONDUCTIVITY MEASUREMENTS OF MOLTEN-SALT FLUXES FROM AN ELEC- \\ TROSLAG REMELTING PROCESS
}

\author{
J. D. Lore
}

July 1974

\section{UNION CARBIDE}

\section{OAK RIDGE Y-12 PLANT} OAK RIDGE, TENNESSEE

prepared for the U.S. ATOMIC ENERGY COMMISSION

under U.S. GOVERNMENT Contract W.7405 eng 26

\section{MASTER}




\section{DISCLAIMER}

This report was prepared as an account of work sponsored by an agency of the United States Government. Neither the United States Government nor any agency Thereof, nor any of their employees, makes any warranty, express or implied, or assumes any legal liability or responsibility for the accuracy, completeness, or usefulness of any information, apparatus, product, or process disclosed, or represents that its use would not infringe privately owned rights. Reference herein to any specific commercial product, process, or service by trade name, trademark, manufacturer, or otherwise does not necessarily constitute or imply its endorsement, recommendation, or favoring by the United States Government or any agency thereof. The views and opinions of authors expressed herein do not necessarily state or reflect those of the United States Government or any agency thereof. 


\section{DISCLAIMER}

Portions of this document may be illegible in electronic image products. Images are produced from the best available original document. 
Reference to a company or product name does not imply approval or recommendation of the product by Union Carbide Corporation or the U.S. Atomic Energy Commission to the exclusion of others that may meet specifications.

\begin{tabular}{|c|}
\hline Printed in the United States of America. Available from \\
National Technical Information Service \\
U.S. Department of Commerce \\
5285 Port Royal Road, Springfield, Virginia 22151 \\
Price: Printed Copy $\$ 4.00 ;$ Microfiche $\$ 1.45$
\end{tabular}

This report was prepared as an account of work sponsored by the United States Government. Neither the United States nor the United States Atomic Energy Commission, nor any of their employees, nor any of their contractors, subcontractors, or their employees, makes any warranty, express or implied, or assumes any legal liability or responsibility for the accuracy, completeness or usefulness of any information, apparatus, product or process disclosed, or represents that its use would not infringe privately owned rights. 


\title{
ELECTRICAL CONDUCTIVITY MEASUREMENTS OF MOLTEN-SALT FLUXES FROM AN ELECTROSLAG REMELTING PROCESS
}

\author{
J. D. Lore \\ Laboratory Development \\ Y.12 Development Division
}

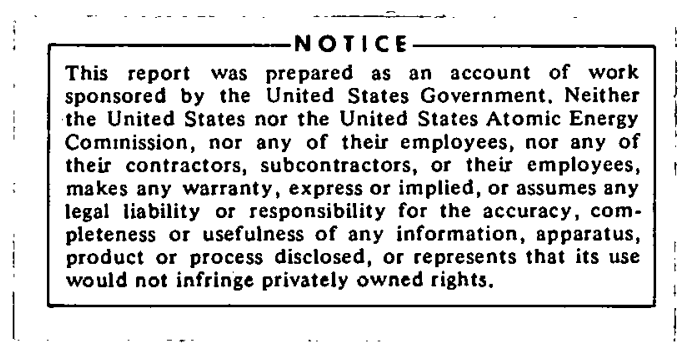

Oak Ridge Y-12 Plant

P.O. $80 \times$ Y. Oak Ridge, Tennessee 37830 


\begin{abstract}
A high-temperature electrical conductivity apparatus has been devised to provide conductivity measurements pertinent to an electroslag remelting process in operation at the Oak Ridge Y-12 Plant. Tests were made on two grades of calcium tluoride and segments of electroslag melt material. Components of undesirable feed and melt material with a relatively lower electrical transport potential were identified.
\end{abstract}




\section{CONTENTS}

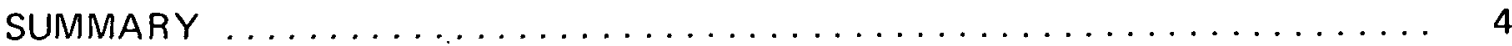

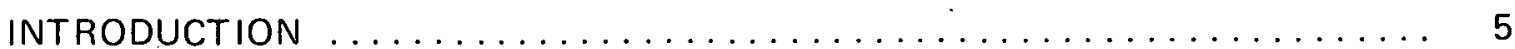

ELECTROSLAG REMELTING PROCESS CONDUCTANCE MEASUREMENTS $\ldots . \quad 6$

Metallurgical Development of the Process $\ldots \ldots \ldots \ldots \ldots \ldots \ldots \ldots \ldots \ldots$

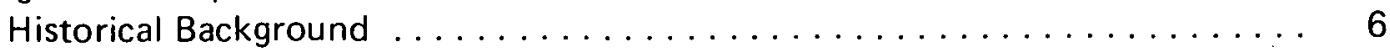

Process Description .......................... 6

Design and Construction of the Electrical Conductivity Apparatus . . . . . . . . . 7

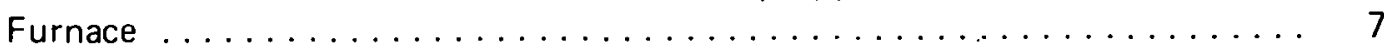

Conductance Cell and Heater Element Assembly ............... 7

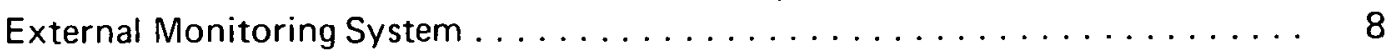

Experimental Measurement Procedure for Calcium Fluoride and Electroslag ....... 9

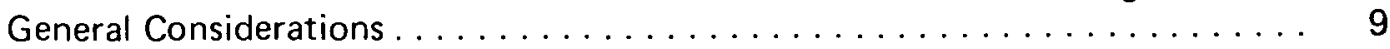

Test Preparation . . . . . . . . . . . . . . . . . . . . . . 10

Electrical Conductivity Measurements for Calcium Fluoride

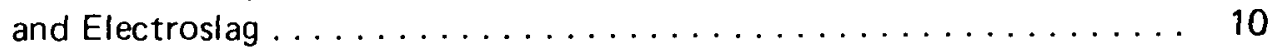

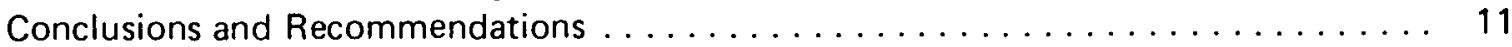

Interpretation of Test Results for the Electroslag

Remelting Process ...................... 11

Future Application of the High-Temperature Electrical

Conductivity Apparatus . . . . . . . . . . . . . . . . 12

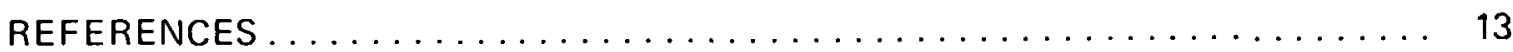

ACKNOWLEDGEMENTS $\ldots \ldots \ldots \ldots \ldots \ldots \ldots \ldots \ldots \ldots \ldots \ldots \ldots \ldots$ 
The electroslag remelting process (ERP), employing calcium fluoride for mulberry recycle, shows promise for being able to produce high-quality material for parts manufacture. A program was conducted to describe the present process and define the causative factors leading to occasional failures. Electrochemical studies at high temperatures were required as a part of this effort.

Design, construction, and development of an apparatus for determining the electrical conductivity of molten electroslag was accomplished, and its application to the ERP developed. The electrical conductivity findings arc in accordance with microanalytical results and suggest a possible means for improving uperating efficiency. 


\section{INTRODUCTION}

Development and implementation of processes for the recovery of thorium, depleted uranium, and uranium alloys were initiated at the Oak Ridge $Y-12$ Plant ${ }^{(a)}$ as a conservation measure. Efficient operation required refinements and optimization of the processes which are based on consumable-electrode remelting of metal that utilizes molten calcium fluoride $\left(\mathrm{CaF}_{2}\right)$. It was established early that oxide impurity buildup in the $\mathrm{CaF}_{2}$ slag (a natural occurrence as the throughput of recycle scrap progressed) reduced operating efficiency. In this connection, electrical conductance measurements at high temperatures were deemed to be necessary for a more quantitative assessment of the operational parameters. This report describes the design and initial application of a laboratory apparatus for conductance measurements of molten salts.

(a) Operated by the Union Carbide Corporation's Nuclear Division for the US Atomic Energy Commission. 


\section{ELECTROSLAG REMELTING PROCESS CONDUCTANCE MEASUREMENTS}

\section{METALLURGICAL DEVELOPMENT OF THE PROCESS}

\section{Historical Background}

A uranium-7.5 niobium-2.5 zirconium alloy (mulberry) is of continuing interest to personnel at the Oak Ridge Y-12 Plant. It was decided to develop an arc-melting recycle process for the mulberry alloy streams. As the process developed, an increase was observed in the number of recycle parts killed because of casting flaws which are now thought to be agglomerates of oxide particles. As a remedy, an electroslag consumable-electrode remelting process $(\bar{E} \bar{R} P)$ was proposed to replace the arc-meli cunsurlable ieinelting opcration. Preliminary success with the ERP was indicated, but a study of material properties and operating parameters was needed to gain confidence in the Plaıl's abulity to reproduclbly obtain satisfactory ingots. Electrical conductance measurements of the molten salt flux were of interest to assess the effect of the oxide impurities on conductivity.

\section{Process Description}

Figure 1 illustrates the method of electroslag consumable electrode melting. Prior to feeding slag material to the furnace, an arc is struck on the hearth plate. The furnace is employed as an arc melter until an adequate molten pool of metal is obtained, then the $\mathrm{CaF}_{2}$ slag material is fed into the arc region until the interelectrode space is filled with molten slag. The current is thus conveyed through a molten salt electrolyte instead of the arc plasma as before. Furnace cunliuls are of the constant voltage type that supply a set voltage to the electrode so that the current depends on the load voltage. As the ingot grows, a thin slag layer is trapped between it and the cold crucible wall. At the end of the melt the power is cut, the electrode withdrawn, and the slag top solidifies.

The top portion of a mulberry ingot was removed from the furnace for evaluation. A typical ingot cross section is illustrated in Figure 2. Sampling locations and more descriptive details are given in the section entitled: EXPERIMENTAL MEASUREMENT PROCEDURE FOR CALCIUM FLUORIDE ELECTROSLAG (Page 9).

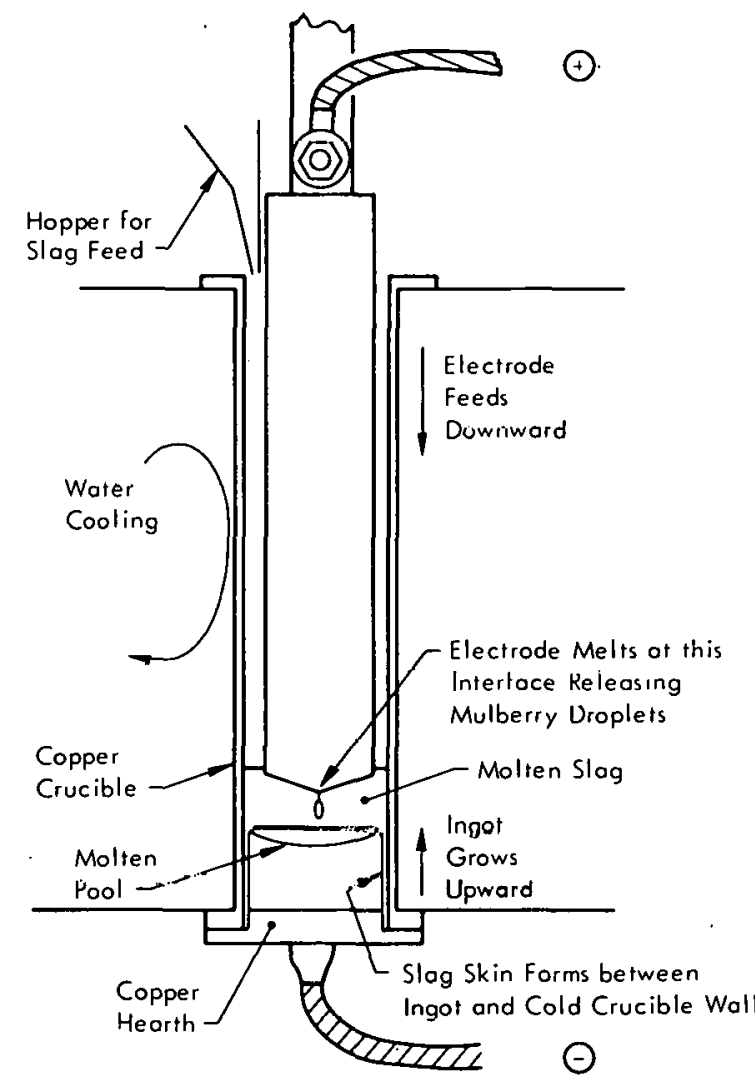

Figure 1. ELECTROSLAG CONSUMABLE-ELECTRODE MELTING FURNACE.

$$
\text { ELECTROSLAG (Page 9). }
$$




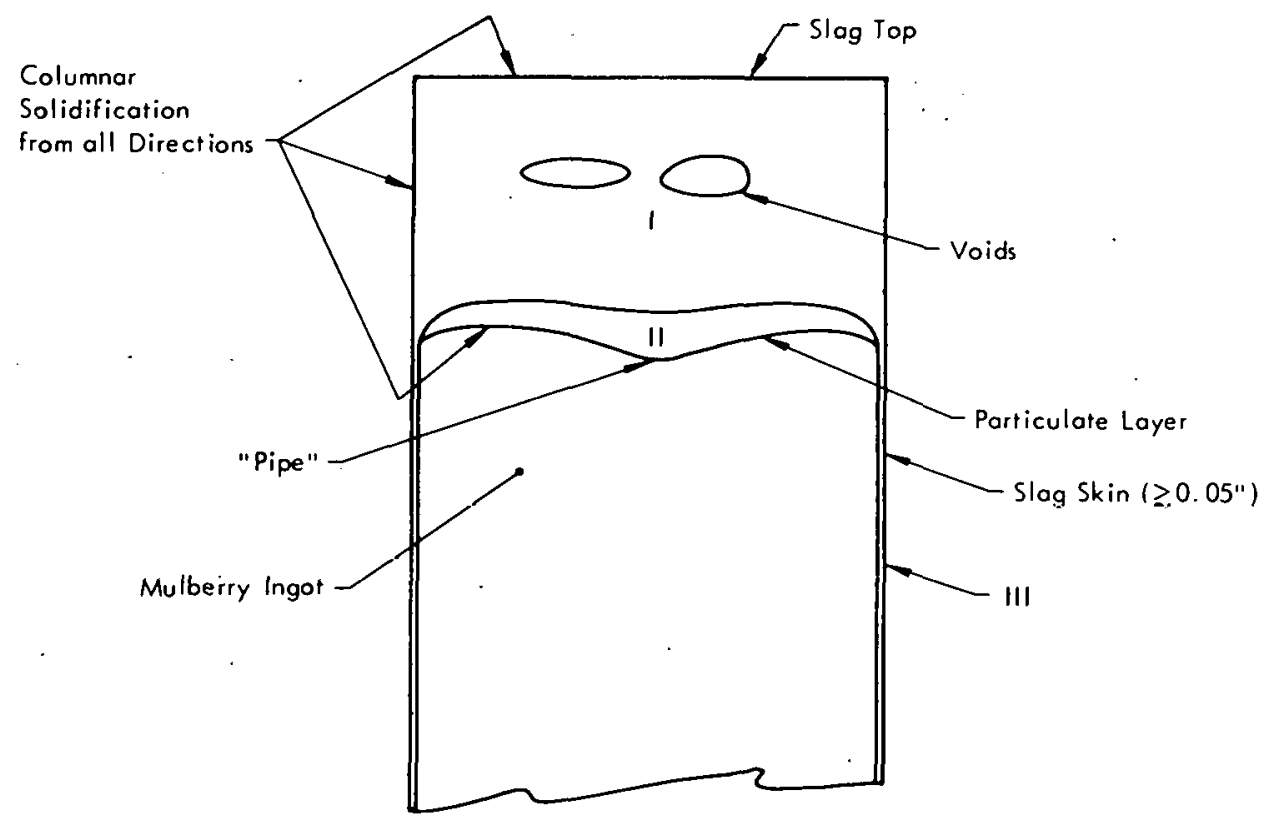

Figure 2. TOP PORTION OF THE MULBERRY INGOT WITH SLAG TOP (IN CROSS SECTION) AS REMOVED FROM THE FURNACE. (Roman Numerals Refer to Regions with in the Ingot)

\section{DESIGN AND CONSTRUCTION OF THE ELECTRICAL CONDUCTIVITY APPARATUS}

\section{Furnace}

A furnace, designed like that of Wagner, (1) for high-temperature thermal expansion measurements to $3000^{\circ} \mathrm{C}(3273 \mathrm{~K})$ was modified to accommodate a combination heater element and conductance cell. The furnace depicted in Figure 2 was constructed in the form of a box, cast from Naval brass, and hinged so that a single panel was fixed. The five other walls of the box comprised the movable section. It may be seen from Figure 3 that this arrangement completely exposes the heater assembly, sample suspension system, thermal radiation shielding, and terminal connections for leads to the external monitoring equipment. When swung shut, a seal between the two sections of the furnace is effected by a Neoprene ring, and the system is ready to be evacuated (or flushed) in preparation for an experiment. The vacuum system consisted of both a mechanical and diffusion pump. Without cold trapping, pressures of $10^{-5}$ torr $\left(1.3 \mathrm{E}-03^{-} \mathrm{Pa}\right)$ are readily obtainable. Conductivity experiments were performed at a slightly positive pressure of approximately $1.0 \mathrm{psig}(6.9 \mathrm{kPag})$ with respect to the ambient surroundings. The walls of the furnace are water cooled. Flow rates of approximately $1 \mathrm{gpm}(6.3 \mathrm{E}-05 \mathrm{~m} 3 / \mathrm{s})$ adequately transfer the heat from the resistance heater element through the furnace walls. The furnace power source consists of two 50-KVA, three-phase, silicon-rectified DC welding supplies connected in parallel to provide 500 to $2000 \mathrm{~A}$ as required for temperature attainment. Although the resultant output signal from the power network had a $3 \% A C$ component, no interference with the measuring bridge circuit was observed.

\section{Conductance Cell and Heater Elemeint Assembly}

The combination conductance cell/heater element assembly is illustrated in Figure 3 . The cell consisted of a hollow, cylindrical heater element into which a boron nitride (BN) 


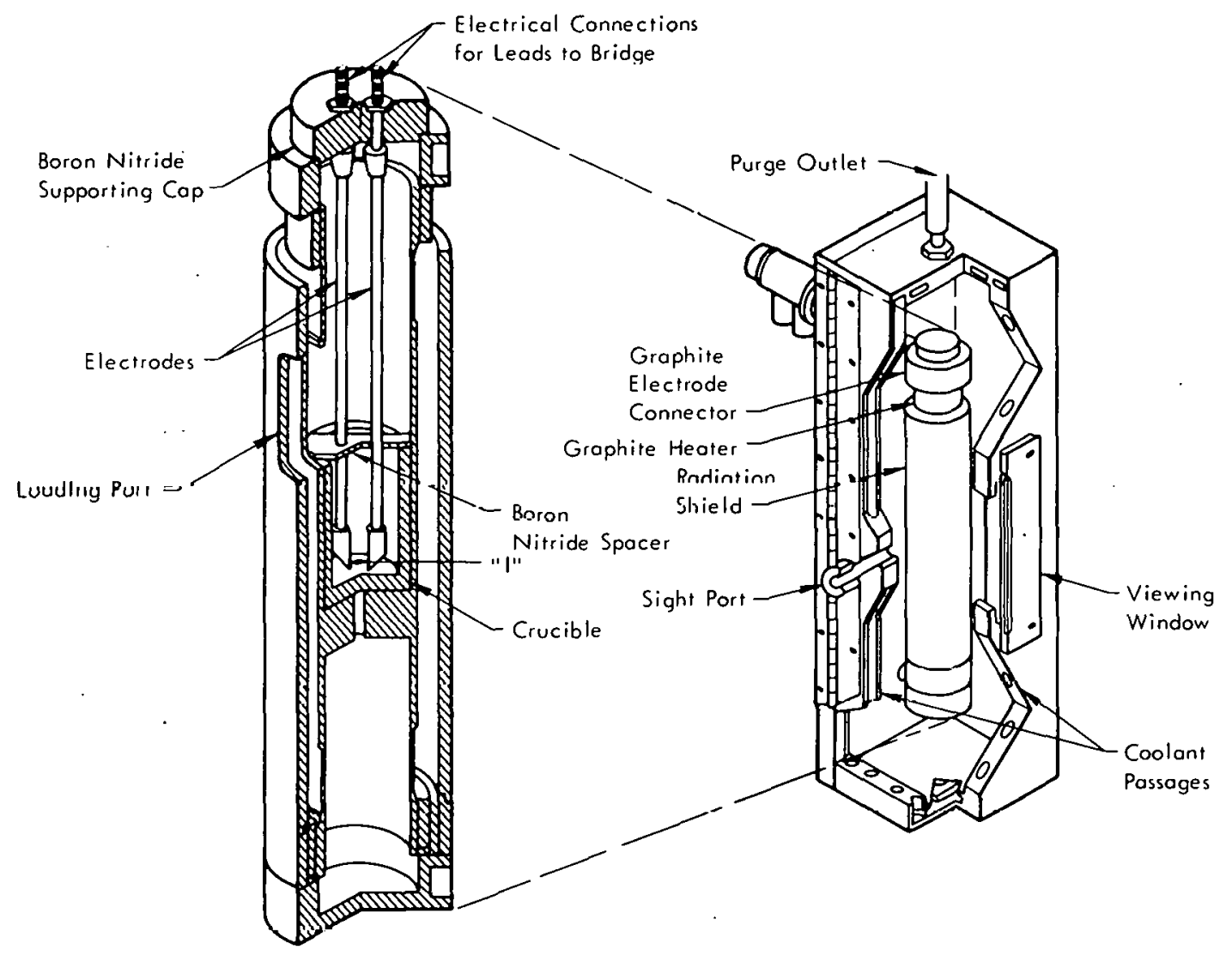

Figure 3. FURNACE, HEATER, AND CONDUCTANCE CELL ASSEMBLY.

crucible was slip fitted for salt containment. Power was conveyed from the DC supply through silver-coated sopper bus bars and traveled through the flat-faced electrode feedthroughs located on the top and bottom of the rear furnace section. The graphite electrode connectors were threaded directly into the electrode stems and, with the cylindrical heater element in place, the power circuit was completed. An adjustable measuring electrode assembly was employed which consisted of two, rigid, flat-faced plates, each with an exposed area of $1.61 \mathrm{~cm}^{2}$ suspended from a BN holder/spacer by $0.32-\mathrm{cm}$-diameter graphite rods. The electrode assembly and crucible were thus supported entirely by the stationary heater element. This arrangement facilitated adjustments of plate separation distance and immersion depth. Most important, a reproducible geometrical cell constant could be maintained. The cell constant (ratio of plate separation to the cross-sectional area) selected for this work was $0.443 \mathrm{~cm}^{-1}$.

\section{External Monitoring System}

The external bridge circuit for resistance measurements is indicated schematically in Figure 4. Referring again to Figure 3 , insulated platinum wire leads $(0.76 \mathrm{~mm})$ were connected from each electrode stem to the external monitoring system. A General Radio. Model 1650-A impedance bridge was chosen for $A C$ resistance measurements because of its adaptability for use with an external frequency generator (Hewlett-Packard Model 200 CD). Also, the capability for series cell capacitance measurements was incorporated into the instrument. 
In Figure 4, the bridge diagram illustrates the matched standard resistors, $R_{A}$ and $R_{B}$ in the upper arms. One lower arm contains the cell of unknown resistance, $R_{X}$ and the other balancing resistance, $R_{n}$, and capacitance, $C_{p}$, connected in parallel. Upon achieving bridge balance:

$$
R_{x}=R_{n} \frac{R_{A}}{R_{B}} .
$$

The bridge circuit was grounded, as noted in Figure 4, but the generator, while separately powered, was ungrounded. A phase-sensitive null detector indicated bridge balance.

\section{EXPERIMENTAL MEASUREMENT PROCEDURE FOR CALCIUM FLUORIDE AND ELECTROSLAG}

\section{General Consiclerations}

Bridge methods are typically employed for electrical conductivity measurements of molten salts, and alternating current is used above $1000^{\circ} \mathrm{C}(1273 \mathrm{~K})$. The voltage source should be sinusoidal and preferably of variable frequency. If measured conductivity is independent of frequency, the cation/anion double-layering effect at the electrode salt interface can be considered as negligible. Variation of the frequency between 1 and $20 \mathrm{kHz}$ had only minor effects ( $\pm 2 \%$ relative) on the bridge balance point. These observations do not exclude or preclude the existence of salt polarization in the $\mathrm{CaF}_{2}$ system, but do indicate that the primary test for its presence was negative. (2) Another phenomenon which can bias electrical conductivity measurements is the internal cell capacitance. Provision was made for balancing out this capacitance by means of a variable capacitor in parallel with Resistor $R_{n}$ in Figure 4. The cell capacitance (on the order of $40 \mu \mathrm{f}$ in molten $\mathrm{CaF}_{2}$ ) would appear to bias the measured resistance values by $10-20 \%$ according to Robbino;(3) but, if so, resistance would be quite dependent on frequency. The observed resistance measurements were, therefore, directly employed to compute the electrical conductivity, $k$, given by the relation:

$$
k=\frac{l}{A} R^{-1}
$$

where:

\& represents the electrode plate separation (in $\mathrm{cm}$ ),
A the area of the exposed plate (in $\mathrm{cm}^{2}$ ), and
$R$ the electrical resistance (in ohms).

I he cross-sectional area of the plates was $1.61 \mathrm{~cm}^{2}$ and tineir separation distance was 0.71 $\mathrm{cm}$ for these experiments. 


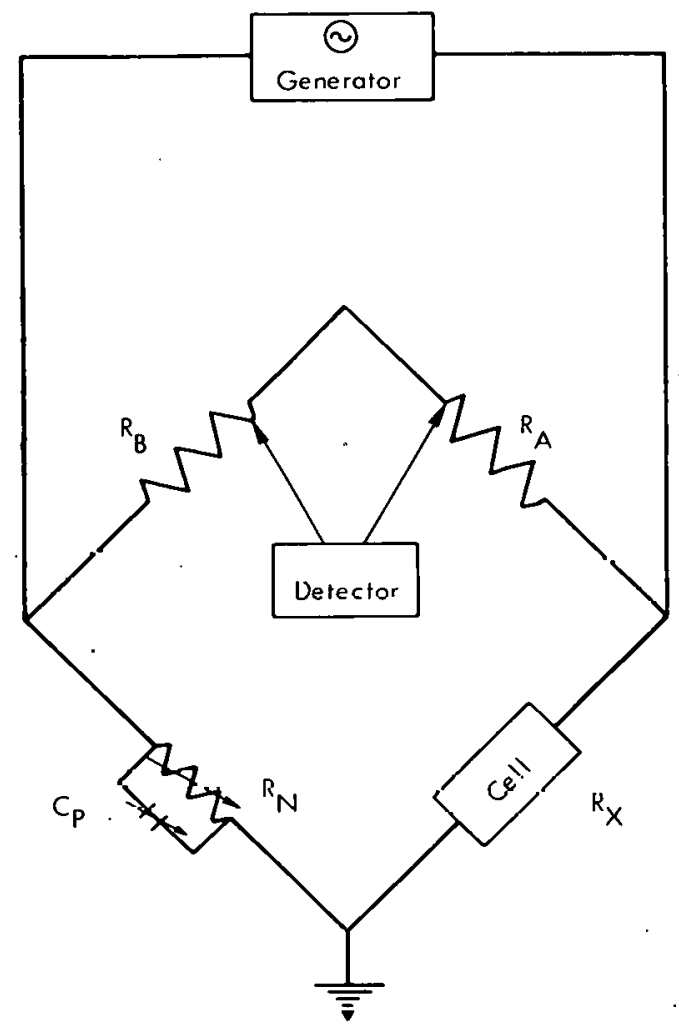

Figure 4. BRIDGE CIRCUIT FOR CONDUCTANCE MEASUREMENTS. .

\section{Test Preparation}

Setup-Assembly of the conductance cell and heater element was accomplished in the following manner: the graphite electrode connectors were threaded directly to the electrode stems which protruded through the furnace wall, as seen in Figure 3. The hollow, cylindrical, graphite heater element was next inserted by lowering it through the connector grips. The top connector was slightly larger than the bottom connector, and the element was likewiso tapered to allow this dnwnward motion. After insertion of the empty BN crucible into the heater well, the electrode assembly was lowered into place and the finely ground salt was loaded into the crucible through the exprised port, carefully tamping the pile for compaction. The pair of half-shell radiation shields, lined with $0.01-\mathrm{mm}$-thick reflective graphite sheet (Grafoil), was next placed in a free-standing position encompassing the heater element and being supported by the bottom electrode connector. A $1 / 8$-inch $(0.32-\mathrm{cm})$ gap between the shield and the top electrode prevented arcing and the passage of current

through the shield. The final assembly operation is to secure the platinum wire leads (insulated with woven asbestos sleeving) to the graphite nut terminals which lock each electrode stem to the BN supporting cap. The door panel is closed and latched, and the furnace is evacuated to 0.05 torr $(6.5 \mathrm{~Pa})$ and backfilled with argon. Testing was conducted at a continuous purge rate of $0.5 \mathrm{scfm}(2.4 \mathrm{E}-04 \mathrm{~m} 3 / \mathrm{s})$.

Calibration - The experimental or working-cell constant was determined for reagent-grade barium chloride $\left(\mathrm{BaCl}_{2}\right)$ at about $1200^{\circ} \mathrm{C}(1473 \mathrm{~K})$, at which temperature a reliable literature value was available. (4) A value for $\ell / A$ of $5.33 \pm 0.05 \mathrm{~cm}^{-1}$ was obtained. Repetitive measurements indicated that this constant was independent of the liquid depth as long as both electrode platens were completely immersed and the meniscus reached the supporting stems (Figure 3). The $\mathrm{BaCl}_{2}$ was melted in a $\mathrm{BN}$ crucible, and some boron contamination $(\sim 600 \mathrm{ppm})$ was noted. The experiment was rerun in a platinum crucible and no cell-constant variation was noted. All experiments involving $\mathrm{CaF}_{2}$ were conducted with the $\mathrm{BN}$ crucible because of its resilience to the higher test temperatures and to the corrosive molten fluoride.

\section{Electrical Conductivity Measurements for Calcium Fluoride and Electroslag}

Electrical conductivity measurements were obtained for $\mathrm{CaF}_{2}$ and typical slag material at temperatures just below their melting points $(>1673 \mathrm{~K})$. Acid-grade $(A G) \mathrm{CaF}_{2}$, the employed electroslag material, and higher-purity, reagent-grade ( $R G$ ) $\mathrm{CaF}_{2}$ powders were 
initially examined to determine if the AG material exhibited a comparable conductivity. Analyses of both grades of $\mathrm{CaF}_{2}$ showed that oxygen was the major contaminant in both materials. RG contained $0.70 \% \mathrm{O}_{2}$ and $\mathrm{AG}$ contained $0.84 \% \mathrm{O}_{2}$ on a dried basis (Leco T-30). As seen in Table 1, the RG sample was more conductive by approximately $7 \%$. The indicated temperature (Table 1) was read with a disappearing, filament-type optical pyrometer, focusing on the back of the heater element. Thus, the measurement temperatures for $R G$ and $A G$, while comparable, were determined by visual observations at equilibrium resistance values and are obviously not indicative of the mean sample temperature or true melting point. The larger RG value was consistent with chemical analyses which indicated its lower oxygen content. Analyses of the melts for boron oxide $\left(\mathrm{B}_{2} \mathrm{O}_{3}\right)$ from the $\mathrm{BN}$ crucible indicated no appreciable boron contamination of either $\mathrm{RG}$ or $\mathrm{AG} \mathrm{CaF}_{2}$ melts.

Table 1

ELECTRICAL CONDUCTIVITY RESULTS FOR CALCIUM FLUORIDE MELTS

\begin{tabular}{|c|c|c|c|c|c|}
\hline \multirow{2}{*}{$\begin{array}{c}\text { Identification } \\
\text { Number }\end{array}$} & \multirow[b]{2}{*}{ Description } & \multicolumn{2}{|c|}{$\begin{array}{l}\text { Observed } \\
\text { Heater Element } \\
\text { Temperature } \\
\end{array}$} & \multirow{2}{*}{$\begin{array}{c}\text { Electrical } \\
\begin{array}{c}\text { Conductivity, } k(1) \\
\left(\Omega^{-1}-\mathrm{cm}^{-1}\right)\end{array}\end{array}$} & \multirow{2}{*}{$\begin{array}{c}\text { Standard } \\
\text { Deviation, } \sigma^{(2)} \\
\left(\Omega^{-1} \mathrm{~cm}^{-1}\right) \\
\end{array}$} \\
\hline & & $\left({ }^{\circ} \mathrm{C}\right)$ & (K) & & \\
\hline 189.24 & Reagent Giade & 1547 & 1820 & $3.56^{(3)}$ & 0.025 \\
\hline 189.26 & Acid Grade & 1542 & 1815 & 3.33 & 0.005 \\
\hline 189.28 & Gray Slag & 1404 & 1677 & 3.29 & 0.086 \\
\hline 189.30 & Red Slag & 1455 & 1728 & 2.56 & 0.27 \\
\hline
\end{tabular}

(1) Cell constant determined with $\mathrm{BaCl}_{2}$ at $1180^{\circ} \mathrm{C}(1453 \mathrm{~K})-(\mathrm{I} / \mathrm{A})=5.33 \mathrm{~cm}^{-1}$.

(2) $\sigma=\left|\frac{n \Sigma k^{2}-(\Sigma k)^{2}}{n(n-1)}\right|^{1 / 2}$, where $n=4$.

(3) Literature value: $4.10 \Omega^{-1}-\mathrm{cm}^{-1}$ at $1550^{\circ} \mathrm{C}$ (1823 K) [Acta Chem Scand, 9 (8).p 1406 (1955)].

The top portion of the mulberry ingot, with the slag cap in cross section as removed from the electroslag furnace, is illustrated in Figure 2. A typical grayish $\mathrm{CaF}_{2}$ sample from the slag cap (described as a good melt) was also examined for electrical conductivity. A red layer at the lower slag extremity (adjacent to the mulberry melt) was similarly tested. This layer consisted of a sedimentary deposit of uranium with $\leqslant 1$ wt \% zirconium metal globules surrounded by the oxides of these metals, including $\sim 1 \mathrm{wt} \% \cup \mathrm{UO}_{2}$. The observed $29 \%$ higher conductivity of the gray material (Table 1) is in accordance with the analytical finding of its higher purity than the red layer.

\section{CONCLUSIONS AND RECOMMENDATIONS}

\section{Interpretation of Test Results for the Electroslag Remelting Process}

Consideration of the electrical conductivity data for the mulberry process corroborates electron microprobe analyses with regard to oxygen contamination. Microanalysis found up to $10 \mathrm{wt} \%$ included oxide particulate material and evidence of its dissolution at ERP operating temperatures. The conductivity data, as reported herein, suggest that the more conductive $\mathrm{RG} \mathrm{CaF}$ and gray slag material (if predominant in the electroslag) would lead to a 
more efficient operation. Cost of the $\mathrm{KG} \mathrm{CaF} 2$, relative to the higher power input requirement for the $A G$ salt and the ease of maintaining slag purity, should be examined to determine the feasibility of appropriate process modifications.

\section{Future Applications of the High-Temperature Electrical Conductivity Apparatus}

Development and application of the test apparatus from the conceptual design and operational stages have verified its utility for electrical conductivity measurements at high temperatures. It was devised with limited objectives; ie, to apply to production problems rather than as a research tool.

Further development of the instrument will depend on future plant needs. 


\section{REFERENCES}

(1) Wagner, Paul; Equipment and Techniques for Measurements of Thermal Conductivity, Thermal Expansion, and Associated Properties Above $1000^{\circ}$ C; LA-DC-9545; December 1967.

(2) Kingery, W. D.; Property Measurements at High Temperatures; Wiley, New York (1959).

(3) Mamantov, Gleb; Molten Salts: Characterization and Analysis; Marcel Dekker, New York (1969).

(4) Janz, G., et al; "Electrical Conductance, Density, and Viscosity Data", National Standard Reference Data System, National Bureau of Standards, 15, Molten Salts, 1 (1969). 


\section{ACKNOWLEDGEMENTS}

The author wishes to thank J. B. Trent of the $Y-12$ Mechanical Design Engineering section who provided detailed design criteria for the electrical conductance cell; M. E. Ward, Plant Laboratory, who developed the test methodology and performed most of the experiments; P. C. Turner and H. L. Richards, Laboratory Development, who provided invaluable technical advice; and J.S. Bullock, IV, Chemistry Development and project coordinator, who afforded considerable insight regarding the ERP process and provided the required samples. 


\section{DISTRIBUTION}

Atomic Energy Commission - Oak Ridge

Hickman, H. D.

Zachry, D. S., Jr

Oak Ridge Gaseous Diffusion Plant

Wilcox, W. J., Jr

Winkel, R. A.

Oak Ridge Y-12 Plant

Alvey, H. E.

Bernander, N. K.

Briscoe, O. W.

Burditt, R. B.

Burkhart, L. E.

Cadden, J. L.

Denny, A.

Dodson, W. H.

Ellingson, R. D.

Foulk, D. L.

Fraser, R. J.

Jacksori, V. C.

Jones, F. W.

Kahl, K. G.

Keith, A.

Kite, H. T.

Lewis, P. S.

Lore, J. D. (15)

Lundin, M. I.

McLendon, J. D.

Oliphant, G. W.

Phillips, L. R.

Richards, H. L.

Rowan, J. H.

Schreyer, J. M.

Smith, J. H.

Smith, R. D.

Stoner, H. H.

Weathersby, W. E.

Whitson, W. K.

Yaggi, W. J./Googin, J. M.
Y-12 Central Files (5)

Y-12 Central Files (master copy)

Y-12 Central Files (route copy)

Y.12 Central Files (Y-12RC)

Paducah Gaseous Diffusion Plant

Levin, R. W.

In addition, this report is distributed in accordance with the category UC-37, Instruments, as given in the USAEC Standard Distribution Lists for Unclassified Scientific and Technical Reports, TID-4500. 